Article

\title{
Benthic Diatom Composition in Coastal Zone of Black Sea, Sasyk Reservoir (Ukraine)
}

\author{
Olena P. Bilous ${ }^{1}{ }^{\circledR}$, Agata Z. Wojtal ${ }^{2, *}$, Natalia O. Ivanova ${ }^{1}\left({ }^{1}\right.$, Petro M. Tsarenko $^{3}$, \\ Olga V. Burova ${ }^{3}$ and Sophia Barinova ${ }^{4}$ D \\ 1 Institute of Hydrobiology, NAS of Ukraine, Geroiv Stalingrada 12, 04210 Kyiv, Ukraine; \\ bilous_olena@ukr.net (O.P.B.); natiwinao@gmail.com (N.O.I.) \\ 2 Institute of Nature Conservation, Polish Academy of Sciences, A. Mickiewicza Ave. 33, \\ 31-120 Kraków, Poland \\ 3 M.G. Kholodny Institute of Botany, National Academy of Sciences of Ukraine, Tereschenkivska Str. 2, \\ 01004 Kyiv, Ukraine; ptsar@ukr.net (P.M.T.); olga_gerasymova@ukr.net (O.V.B.) \\ 4 Institute of Evolution, University of Haifa, Mount Carmel, Abba Khoushi Ave. 199, Haifa 3498838, Israel; \\ sophia@evo.haifa.ac.il \\ * Correspondence: wojtal@iop.krakow.pl
}

Received: 17 October 2020; Accepted: 27 November 2020; Published: 1 December 2020

\begin{abstract}
The Sasyk Reservoir is one of the largest seaside reservoirs in Ukraine, artificially maintained as a freshwater area including various floodplain areas. The Reservoir originated from an estuary to now being an almost freshwater reservoir. The diatoms (Bacillariophyta) in benthos were investigated for analyzing the coastal zone diversity of the Black Sea inside the borders of Ukraine. The indicated diatom composition was formed by 97 species (100 infraspecies taxa). Some rare marine and freshwater taxa were noted, as well as three species reported in Ukrainian territory for the first time (Navicula vandamii Schoeman et R.E.M. Archibald, Sellaphora difficillima (Hustedt) C.E. Wetzel, L. Ector et D.G. Mann, and Mastogloia laterostrata Hustedt). The bioindicative characteristics of the diatom composition testified to the freshwater condition of the reservoir. Changes to the salinity level of the Sasyk Reservoir were exposed due to the composition of benthic diatoms. The presence of mesohalobous species (7 taxa) acknowledges conditions that are typical for estuaries and mouths of rivers and reveals the salinity changes in the Sasyk Reservoir. Likewise, the prevailing number of oligohalobous diatoms (61 taxa) reveal presence of freshwater in the reservoir. The implementation of the Polish phytobenthos lake assessment method for the nearby Ukrainian Reservoir was conducted for the first time. The multimetric Diatom Index for lake values varied from 0.39 to 0.76 , and revealed alterations in the status over the Sasyk sites, ranging from good, moderate, to poor. Thus, it may be concluded that the current ecological status relating to the composition of benthic diatoms of the reservoir located in the coastal zone of the Black Sea is evaluated as having a moderate status class with some exceptions.
\end{abstract}

Keywords: phytobenthos; diatoms; new and rare taxa in Ukraine; salinity; coastal zone; Sasyk Reservoir

\section{Introduction}

Phytobenthos is widely recognized as a sensitive indicator to many environmental variables in rivers, streams, and lakes [1-7]. In this matter, a composition of diatom algae is considered as the most important component of benthic flora. Diatoms are sensitive to many environmental factors, including light, temperature, current velocity, salinity, $\mathrm{pH}$, oxygen, as well as to the degree and nature of pollution of the waterbody [8-10]. Beyond that, diatoms are used in neo- and paleolimnological studies for characterizing climatic changes, along with characteristics of eutrophication and trophic 
state conditions [11,12]. Thus, studying benthic diatom species composition has been a major issue regarding water quality management worldwide for many years [13,14].

The study of diatoms of coastal ecosystems is relevant for the Ukraine and many countries of the world covering different continents [15-20]. This is one of the most important issues in establishing natural and anthropogenic changes in transitional waters of the discussed ecosystems and their possible transformations following monitoring studies [16,21,22].

The Sasyk Reservoir, located in Ukraine, could serve as an illustrative example on how diatoms affect salinity changes over the long-term. The Sasyk Reservoir is a unique example of the desalination of a waterbody in Ukraine. In its original natural state, it was a shallow brackish-water lake (estuary) with periodic connection to the sea. In the 1980s, it had an influence of anthropogenic transformation created by an artificial channel, which connected the area with the waters of the Danube River. During the last 40 years (1979-1980 till now) there were fundamental changes to the functioning of this ecosystem, as almost twice the entire volume of the reservoir was pumped out and replaced with water from the Danube (for more details, see [23,24]).

The history of this waterbody shows that sometimes it was described as a "lake", although that does not allow one to distinguish the period covering its transformation. Thus, by calling Sasyk a Reservoir, it becomes clear that this relates to the modern period of the waterbody. If the meaning used in the earlier times (before its transformation), then it should be called a "lake" or "reservoir-lake" [24]. This has created enormous interest in the Sasyk Reservoir, shown by the many disputes regarding its ability to try to reconnect with the Black Sea and its relevance for the growing tourist development in the region [25-29].

The diatoms composition can also be used to describe the characteristics of the ecological status of the Sasyk Reservoir. This is of high importance as the degradation of its status may indirectly affect the coastal and transitional waters of the Black Sea basin region countries, as well as for the Black Sea as a whole. The reason for this is relevant when looking at the much-debated matter of demolishing the dam and reuniting it with the sea for restoring the existing hydromorphology [30,31]. Moreover, the northern part of the Sasyk Reservoir is a national nature park. The Reservoir represents the Ramsar site no. 762, which is a wetland, famous for emergent and submergent plants, including salt meadows, which support nationally rare and relic species, as well as for migratory and breeding (25,000 pairs) water birds [32]. Thus, the ecology of this region and its hydromorphological changes are vital, and attention is needed in order to attract the attention of, not only the scientists, but also the international community.

To try and describe the current situation with this waterbody, macrophytes, phytoplankton, macrozoobenthos, zooplankton, and ichthyofauna were investigated $[18,25,26,33]$. However, no detailed phytobenthic studies have been conducted since 1987. In accordance with the current ideas about the ecological significance of transitional waters and its biodiversity, the aim of our research concerns the features of the differentiation of the benthic diatom assemblages of the Sasyk Reservoir, and the process of changing its salinity during anthropogenic changes to the ecosystem.

\section{Materials and Methods}

\subsection{Study Area}

The Sasyk Reservoir occupies an area of $206 \mathrm{~km}^{2}$, with a maximum length of $31,000 \mathrm{~m}$, and a maximum width of $12,000 \mathrm{~m}$ located $45^{\circ} 40^{\prime} \mathrm{N} 29^{\circ} 41^{\prime} \mathrm{E}$. Its volume equals $479 \mathrm{~km}^{3}$, with an average depth of $2.1 \mathrm{~m}$, with a maximum depth of $3.2 \mathrm{~m}$ (original morphometric characteristics). It has influenced the waters from the Sarata and Kogylnik Rivers, as well as the Danube-Sasyk Canal. The range of totally dissolved solids (TDS) over a year had a wide range of values from 0.3 to $2.7 \mathrm{~g} \cdot \mathrm{L}^{-1}$ whereas before the reservoir creation, it varied between 2.4 and $20.3 \mathrm{~g} \cdot \mathrm{L}^{-1}$ [24].

A sampling campaign was undertaken in the late summer (16.08 and 19.08) of 2018. To cover the total length of the waterbody, 7 sites were located evenly along the banks of the reservoir (Table 1 , 
Figure 1). Diatom assemblages were sampled in the benthos of the Sasyk Reservoir from the same depth at all sites, which equaled a depth to $0.15 \mathrm{~m}$. The relative transparency was higher as the bottom was visible. The substrate from which the samples were taken, at almost all stations, were from the stones of an artificial dam. However, site 7 was from clay and sand from the reed thickets, but nowhere were samples taken from the reed stems themselves. The amplitude of daily fluctuations in the water levels varied from 3 to $16 \mathrm{~cm}$, while the average annual amplitude of water level fluctuations was approximately $38-76 \mathrm{~cm}$. The change in water level in most cases was influenced by the artificial regulation of water exchange (sluices on the Danube-Sasyk Canal and a sluice for discharging water into the sea), as well as the active reaction of the reservoir to the wind. The duration of squeeze on the reservoir was $1-2$ days. When the level of about $10 \mathrm{~cm}$ is displaced, its mark almost returns to its previous value the following day.

Table 1. Mean environmental data showing standard deviation (SD) and GIS coordinates from the sampling points on the Sasyk Reservoir during August 2018.

\begin{tabular}{cccccc}
\hline Site & \multicolumn{2}{c}{ Coordinates } & Water Temperature, ${ }^{\circ} \mathrm{C}$ & Salinity, $\mathbf{g} \cdot \mathbf{L}^{-\mathbf{1}}$ (ppt) & Conductivity mS cm $^{-1}$ \\
\hline 1 & $45^{\circ} 32^{\prime} 25.41^{\prime \prime} \mathrm{N}$ & $29^{\circ} 39^{\prime} 17.76^{\prime \prime} \mathrm{E}$ & $22.35 \pm 0.17$ & $2.06 \pm 0.54$ & $2.81 \pm 0.52$ \\
2 & $45^{\circ} 34^{\prime} 19.54^{\prime \prime} \mathrm{N}$ & $29^{\circ} 41^{\prime} 41.17^{\prime \prime} \mathrm{E}$ & $23.70 \pm 0.12$ & $2.27 \pm 0.57$ & $3.08 \pm 0.57$ \\
3 & $45^{\circ} 37^{\prime} 20.65^{\prime \prime} \mathrm{N}$ & $29^{\circ} 44^{\prime} 1.51^{\prime \prime} \mathrm{E}$ & $25.25 \pm 0.17$ & $2.31 \pm 0.54$ & $3.09 \pm 0.57$ \\
4 & $45^{\circ} 41^{\prime} 39.63^{\prime \prime} \mathrm{N}$ & $29^{\circ} 41^{\prime} 30.76^{\prime \prime} \mathrm{E}$ & $26.70 \pm 0.12$ & $2.16 \pm 0.49$ & $2.84 \pm 0.48$ \\
5 & $45^{\circ} 43^{\prime} 36.85^{\prime \prime} \mathrm{N}$ & $29^{\circ} 41^{\prime} 16.14^{\prime \prime} \mathrm{E}$ & $26.80 \pm 0.12$ & $2.29 \pm 0.55$ & $3.07 \pm 0.55$ \\
6 & $45^{\circ} 33^{\prime} 30.44^{\prime \prime} \mathrm{N}$ & $29^{\circ} 36^{\prime} 26.56^{\prime \prime} \mathrm{E}$ & $26.60 \pm 0.23$ & $0.49 \pm 0.15$ & $0.71 \pm 0.16$ \\
7 & $45^{\circ} 36^{\prime} 12.09^{\prime \prime} \mathrm{N}$ & $29^{\circ} 36^{\prime} 23.76^{\prime \prime} \mathrm{E}$ & $26.40 \pm 0.23$ & $2.19 \pm 0.52$ & $2.93 \pm 0.52$ \\
\hline
\end{tabular}

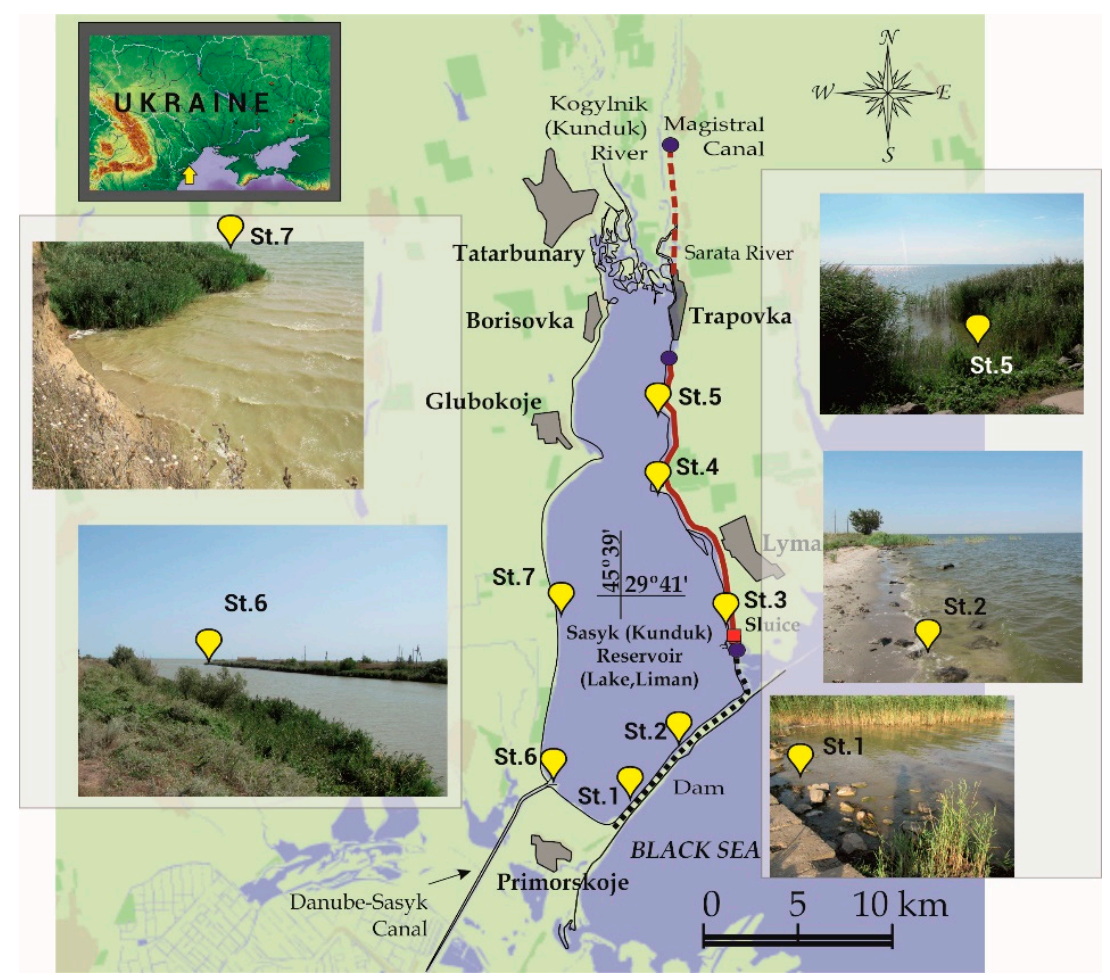

Figure 1. Diatom sampling locations at the Sasyk Reservoir during August 2018.

\subsection{Sampling Strategy}

The phytobenthos was taken from the same depths $(10 \mathrm{~cm}$ below the surface of the water), washed with a toothbrush, fixed with formaldehyde ( $4 \%$ ) on site, and then transported to the laboratory. Altogether, 21 benthic samples from the sites at the Sasyk Reservoir were investigated.

The diatoms were cleaned with hydrochloric acid and hydrogen peroxide, then rinsed in distilled water and mounted with Naphrax ${ }^{\circledR}$ mounting medium [34]. 
The diatoms were identified with a Nikon Eclipse 6600 light microscope with 10 HCX PLAN objective, 100 $\times$ oil immersion objective lens, and Nikon Eclipse 80i, with Plan apochromat (PLAN APO), with 100× differential interference contrast (DIC) objective. For representativeness and accurate future assessments, a minimum of 400 valves were counted per slide. Identification was followed: Süßwasserflora von Mitteleuropa [35-38], with some newer updates [39-41]. The taxonomical system of diatom algae according to Medlin and Kaczmarska [42], with the latest refinements in the nomenclature changes and rectification for certain genera [41,43], were used for this work.

The results of the Reservoir assessment obtained by using the Polish method based on phytobenthic diatoms had never been used before for Ukrainian water bodies, but was assumed a suitable method for ecological status assessment. The purpose of implementing the "multimeric Diatom Index for Lakes" (IOJ) is to assess the trophic state of the reservoir. The index was calculated using JEZIORA software and the values were divided into five group status classes with the following ranges: high $>0.705$, good $\geq 0.590$, moderate $\geq 0.400$, bad $\geq 0.150$ poor, $<0.150$ [44,45].

The ecological classification of diatom species provided for salinity (halobien system) $(\mathrm{H})$ was according to the system of van Dam et al. [10], with basis of Hustedt [46]. Most of the common taxa were already classified by these authors and some additional information, along with modern taxonomical changes invoked from the monograph [47] was included.

The Total Dissolved Solids (TDS) were comprised of inorganic matter, such as minerals, salts, metals as well as dissolved organic compounds present in the water $[48,49]$. The classical sub division of TDS and salinity was presented according to $[45,50]$ : freshwater $<1 \mathrm{~g} \mathrm{~L}^{-1} \mathrm{TDS}$ and $<0.5 \mathrm{~g} \mathrm{~L}^{-1}$ salinity, brackish water 1-5 g L $\mathrm{g}^{-1}$ TDS and 0.5-17 $\mathrm{g} \mathrm{L}^{-1}$ salinity, sea water $30-40 \mathrm{~g} \mathrm{~L}^{-1}$ TDS and 35-40 $\mathrm{g} \mathrm{L}^{-1}$ salinity, brine $\geq 100 \mathrm{~g} \mathrm{~L}^{-1}$ TDS and $\geq 50 \mathrm{~g} \mathrm{~L}^{-1}$ salinity. Thus, the combined classification systems of TDS, chloride concentrations in water, and algal bioindicator correspondence are the following [47]: $<100 \mathrm{CI}^{-} \mathrm{mg} \mathrm{L}^{-1}, 0.2 \mathrm{~g} \mathrm{~L}^{-1}$ salinity-fresh (halophobes, hb), $<500 \mathrm{CI}^{-} \mathrm{mg} \mathrm{L}^{-1}$, salinity $0.9 \mathrm{~g} \mathrm{~L}^{-1}$-fresh brackish (indifferent, i), 500-1000 $\mathrm{CI}^{-} \mathrm{mg} \mathrm{L}^{-1}$, salinity $0.9-1.8 \mathrm{~g} \mathrm{~L}^{-1}$ - brackish fresh (halophiles, hl), 1000-5000 $\mathrm{CI}^{-} \mathrm{mg} \mathrm{L}^{-1}$, salinity 1.8-9.0 $\mathrm{g} \mathrm{L}^{-1}$-brackish (mesohalobes, $\mathrm{mh}$ ).

\subsection{Statistical Data Analysis}

Environmental mapping was carried out in the Statistica 12.0 program according to the parameter values and geographic coordinates of each station. A calculation of similarity was conducted as the network analysis in JASP on the botnet package in R Statistica package of [51]. The results are represented the plot construction on the maximal similarity level of the data on the sampling stations on the level of similarity $50 \%$ and a significant calculation only.

\section{Results}

\subsection{Benthic Diatom Diversity}

Benthic diatom composition in the coastal zone of the Black Sea is presented for the Sasyk Reservoir. Investigations revealed 97 diatom species (100 with infraspecies taxa), belonging to 38 genera of diatom algae during sampling period (Appendix A, Table S1). The main genera are the following: Nitzschia-16, Navicula-12, Cocconeis-6, Amphora, Cymbella, Epithemia, and Tryblionella-5 of each, Staurosira-4, Fragilaria, Gomphonema, and Planothidium-3 of each. All of the named genera are common for diatom communities of nearby territories [52-54].

The composition over the sampling sites had some similar features between each other, and for defining them, a network plot was built (Figure 2).

From Figure 2, it is noticeable that the greatest similarity of data are observed at sampling sites 1,2 , and 4 . These sites are similar to a lesser degree than sites 3 and 5. All of these named sampling points are grouped in the southern part and along the left bank of the Sasyk Reservoir on Figure 1. It is interesting to note, in this context, that site 5 has a negative similarity with sites 2,6 , and 7 , which makes its community the most contrastive in relation to the rest. This, in our opinion, confirms the connection 
with its location, which is closest to the mouth of the Sarata and Kogylnik Rivers. In turn, it reflects the impact of the Danube River, where its waters enter the Sasyk area. The difference in species composition over the sampling points in such a relatively small area reveal the impact of the water heterogenic conditions of the Reservoir. Other assumptions were the effects of wind over the sampling points, reflected in a diverse composition. The noticed hypothesis is confirmed by previous investigations of scientific studies for this territory [24-26,33].

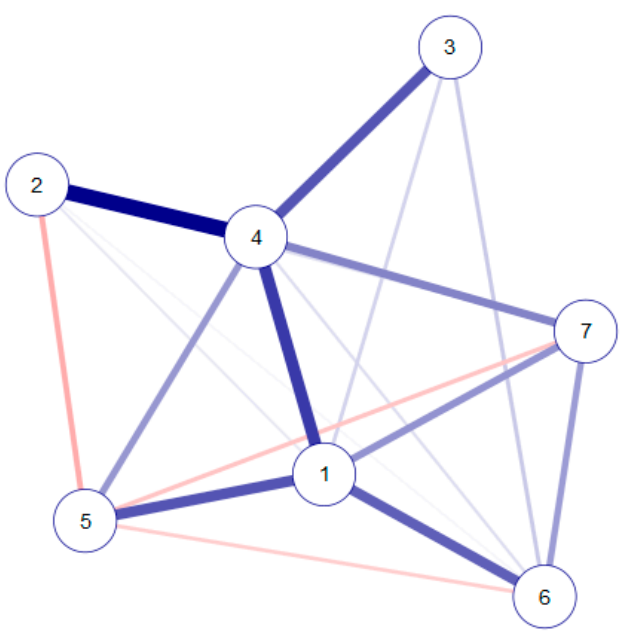

Figure 2. The network plot of the similarity (significant only) between sampling points data of the Sasyk Reservoir in August 2018. The names of sampling stations correspond to Table 1 and Figure 1. The line thickness between stations reflect the correlation value, blue is positive, red is negative.

The series of statistically generated maps illustratively reveal the main parameters of the Sasyk during the investigated period and give us a possibility to assess the admitted factors (Figure 3). Figure 3 demonstrates the highest number of diatom species in phytobenthos in the zone, where the mixing of fresh and brackish waters take place to the southern part of the reservoir.

The following species were present in permanent slides and composed of more than $10 \%$ of its relative abundance for diatom flora covering each sampling point of the Reservoir: Amphora ovalis (Kützing) Kützing, A. pediculus (Kützing) Grunow, Cocconeis neodiminuta Krammer, C. pediculus Ehrenberg, Diatoma moniliformis(Kützing) D.M. Williams, Encyonema cespitosum Kützing, Epithemia gibba (Ehrenberg) Kützing, E. parallela (Grunow) Ruck et Nakov, E. sorex Kützing, Fragilaria radians (Kützing) D.M. Williams et Round, Navicula cryptotenella Lange-Bertalot, Nitzschia inconspicua Grunow, Rhoicosphenia abbreviata (C. Agardh) Lange-Bertalot, and Tabularia fasciculata (C. Agardh) D.M. Williams et Round (Table S1).

Among the all identified species, three species were new, and 13 taxa were rare for the Ukrainian flora (Table S1). The species noted in Ukraine for the first time were presented by: Navicula vandamii Schoeman et R.E.M. Archibald, Sellaphora difficillima (Hustedt) C.E. Wetzel, L. Ector et D.G. Mann, and Mastogloia laterostrata Hustedt. Navicula vandamii and Mastogloia laterostrata are well known in brackish coastal waters [15]. They were found in Sasyk Reservoir at sites 4 and 6 (Table S1). The third species-Sellaphora difficillima-is known from waters of contrasting features, which have small values of salinity. Among the rare species for the Ukraine, diatoms were found: Amphora copulata (Kützing) Schoeman \& R.E.M. Archibald, A. inariensis Krammer, Cymbella compacta Østrup, C. proxima Reimer, Fallacia clepsidroides Witkowski, Gomphonema utae Lange-Bertalot \& E. Reichardt, Navicula lundii E. Reichardt, Nitzschia filiformis var. conferta (P.G. Richter) Lange-Bertalot (=N. conferta (P.G. Richter) Migula), N. supralitorea Lange-Bertalot, Opephora mutabilis (Grunow) Sabbe et Wyverman (=O. olsenii M. Møller), Paraplaconeis minor (Grunow) Lange-Bertalot (= Placoneis minor (Grunow) Lange-Bertalot), Rhaphoneis amphiceros (Ehrenberg) Ehrenberg, and Staurosira construens var. triundulata (Reichelt) $\mathrm{H}$. Kobayasi (Table S1). Most of the rare species for Sasyk were found near 1 and 6 sampling points, 
while other species were found at different sampling points (for details see Table S1). For other species found at different sampling points, it should be noted that the Sasyk has specific conditions and interesting history, which is reflected on the algae composition over its territory.

\subsection{Ecological Characteristics of the Sasyk Sites}

The water temperature fluctuated within a small range $\left(22.35 \pm 0.17-26.80 \pm 0.12{ }^{\circ} \mathrm{C}\right)$, but the analysis demonstrates the highest values in the northern part (Table 1, Figure 3b). This can be explained by the general shallowness of the southern part of the reservoir and the natural change in water temperature during the day. The conductivity measuring revealed aligned values over the waterbody, from $2.81 \pm 0.52$ to $3.09 \pm 0.57 \mathrm{mS} \mathrm{cm}^{-1}$, and near the site no. 6 due to the impact of waters coming from the Danube-Sasyk Canal that it significantly differed and presented $0.71 \pm 0.16 \mathrm{mS} \mathrm{cm}^{-1}$ (Table 1).

The multimeric Diatom Index for Lakes (IOJ) for assessing the trophic state of a reservoir was calculated. The values varied from 0.39 to 0.76 ; at site 1 , it equaled 0.47 , site $2-0.56$, site $3-0.76$, site $4-0.60$, site $5-0.43$, site $6-0.39$, site 7-0.40. According to the Water Framework Directive classification scheme for water quality, these values were divided between five status classes: high, good, moderate, poor, and bad. It occurred that sites no. 1 , no. 2 , no. 4 , and no. 5 had moderate status class, while site no. 3 corresponded to good status and sites no. 6 and no. 7-poor. As can be observed in Figure 3c, the values are highest at the eastern part of the waterbody, which distinguishes it as having the worst quality from all the investigated sampling points (moderate for this case).
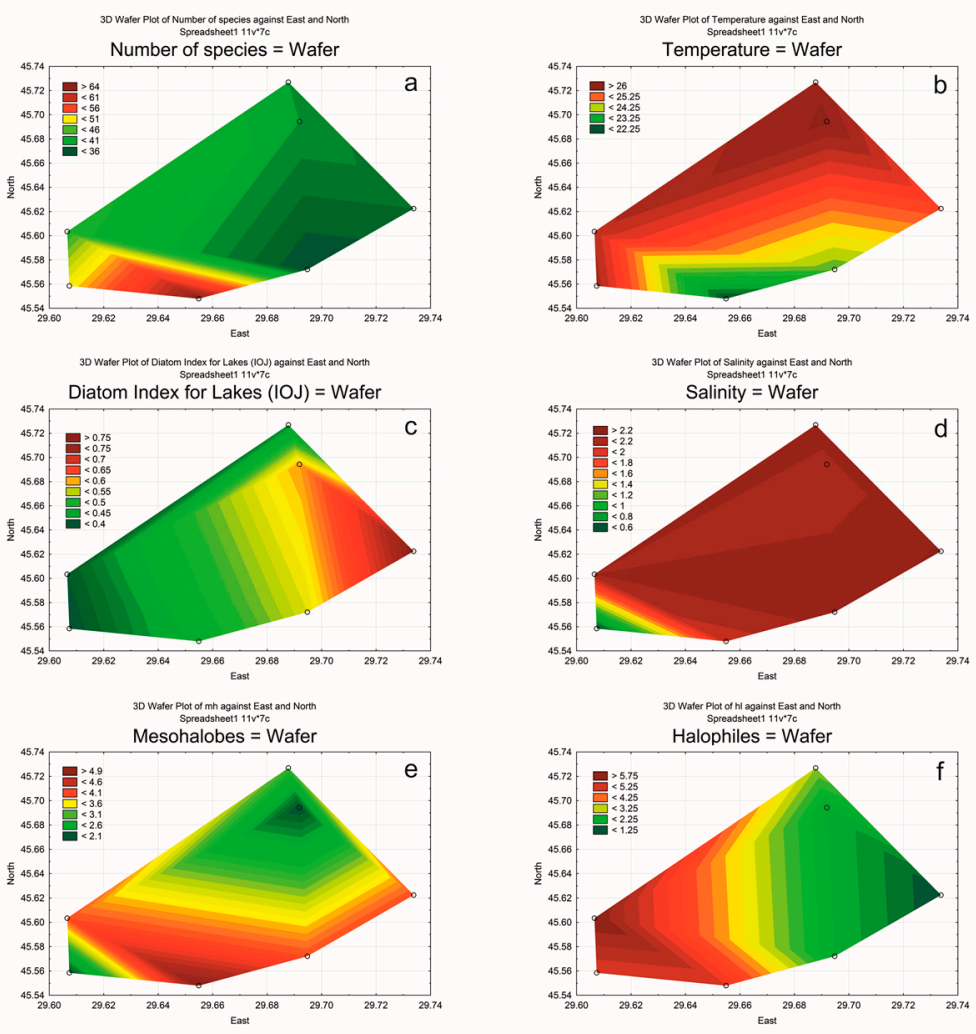

Figure 3. Statistically generated maps of phytobenthic assemblage data from Table 1 and Table S1 ((a) - number of species, (e)—mesohalobes, and (f) - halophiles indicators). (c)—Diatom Index for the lakes as well as chemical parameters of water $((\mathbf{b})$ - temperature and $(\mathbf{d})$ - salinity) on the surface water of the Sasyk Reservoir during August 2018. 


\subsection{Bioindication of Salinity in Sasyk Reservoir}

The measurements of the salinity distributed itself quite evenly across the reservoir, fluctuated by a small range (from $2.06 \pm 0.54$ to $2.31 \pm 0.54 \mathrm{~g} \mathrm{~L}^{-1}$ ) (Table 1). The effect of freshening $\left(0.49 \pm 0.15 \mathrm{~g} \mathrm{~L}^{-1}\right)$ from the Danube-Sasyk Canal is also visible in the map of Figure 3d. The whole taxa list was assessed, concerning the salinity and list of indicator species, including 68 taxa from 100 diatom species that were found in the Sasyk Reservoir. The indicators of salinity were grouped to oligohalobes-halophobes (hb) —2, oligohalobes-indifferents (i)—49, oligohalobes-halophiles (hl)—10, and mesohalobes (mh) — (Figure 4, Table 2).

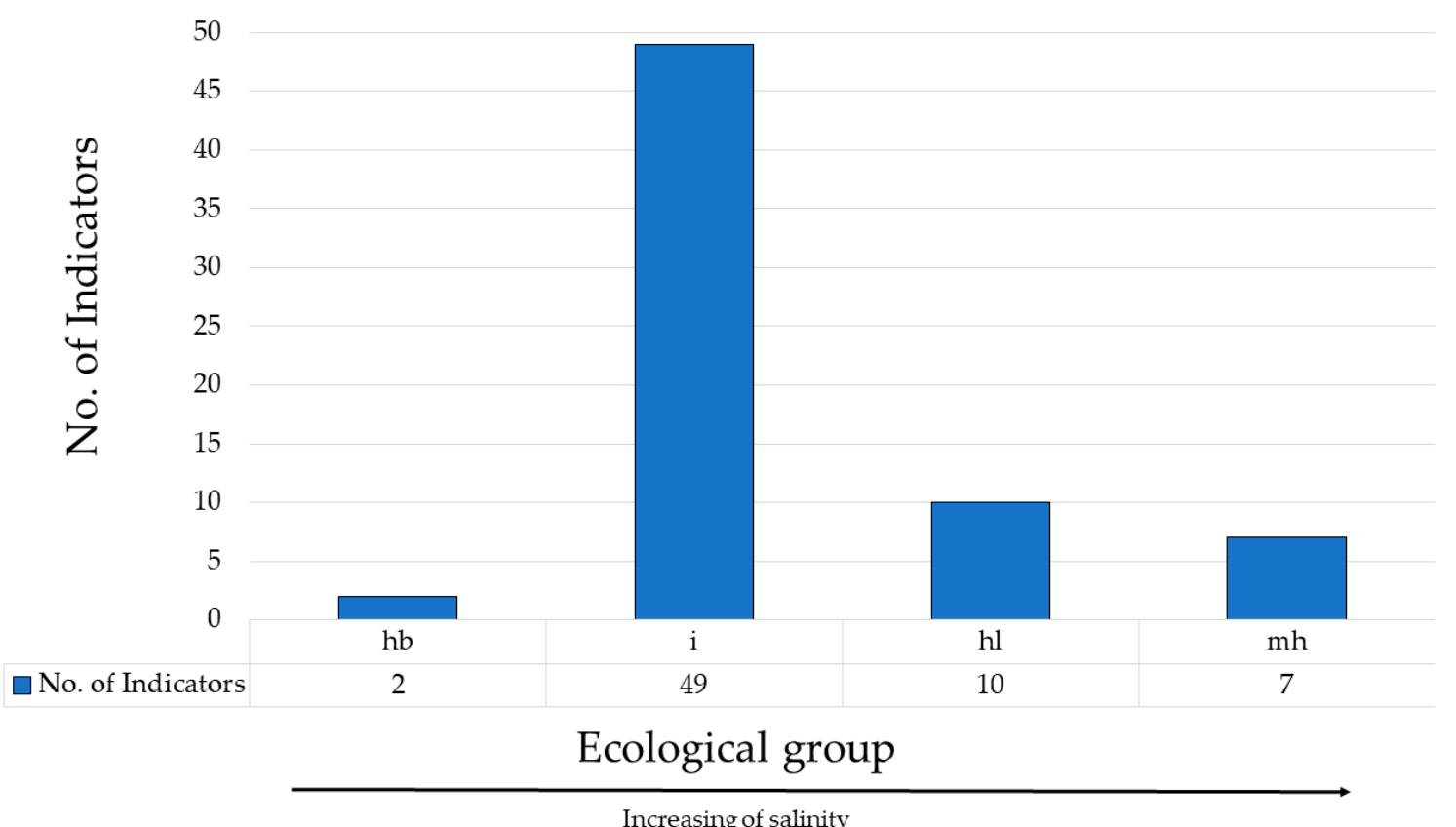

Figure 4. Delineation of salinity (halobien system, H) indicators in Sasyk Reservoir during the August 2018.

Table 2. Species indicators of salinity (according Hustedt, 1938-1939, Barinova et al., 2019) extracted from the sampling stations at the Sasyk Reservoir during August 2018.

\begin{tabular}{cccccccc}
\hline Halobien Indicators & \multicolumn{7}{c}{ Sites } \\
\cline { 2 - 8 } & $\mathbf{1}$ & $\mathbf{2}$ & $\mathbf{3}$ & $\mathbf{4}$ & $\mathbf{5}$ & $\mathbf{6}$ & $\mathbf{7}$ \\
\hline mh (mesohalobes) & 5 & 4 & 4 & 2 & 3 & 2 & 4 \\
$\mathrm{hl}$ (oligohalobes-halophiles) & 5 & 2 & 1 & 2 & 3 & 5 & 6 \\
$\mathrm{i}$ (oligohalobes-indifferents) & 36 & 20 & 28 & 28 & 23 & 30 & 24 \\
$\mathrm{hb}$ (oligohalobes-halophobes) & 1 & 1 & 2 & 1 & 1 & 2 & 1 \\
Total & 47 & 27 & 35 & 33 & 30 & 39 & 35 \\
\hline
\end{tabular}

The figure was built according to indicator values by increasing level of salinity with the following abbreviations: $\mathrm{hb}$-oligohalobes-halophobes, $\mathrm{i}$-oligohalobes-indifferents, $\mathrm{hl}$-oligohalobeshalophiles, $\mathrm{mh}$-mesohalobes.

The characteristics of the Sasyk Reservoir, according to its salinity level, becomes more representative when it comes to the numbers of certain species as shown by the indicator's delineation over the stations (Table 2). Small amounts of mesohalobes (mh) are noticeable at sites 4-6. However, the relative amounts of this group show that only sites 4 and 6 in the reservoir had less than $10 \%$ presence of mesohalobes, 6 and $5 \%$ correspondingly. Thus, the prevailing impact of salinity 
indicators-mesohalobes in the dam area, illustratively demonstrates Figure 3e. In turn, the halophiles group of indicators were present near the dam and southern part of the area (Figure 3f).

\section{Discussion}

\subsection{Biodiversity of the Sasyk Reservoir}

The coastal zone of the Black Sea may be characterized by the biodiversity of the reservoirs or estuaries, which are located there. The results of our work demonstrate the vast diversity of the benthic diatom assemblages over the sites of the Sasyk Reservoir (Table S1). Previous work also noticed the leading role of diatoms along with a high diversity of Cyanophyta during investigations of the phytoplankton in the reservoir $[18,25,26,33]$. The prevalence of Bacillariophyta in the mentioned different ecological groups of algae might be explained by the shallow depths as well as the water mixing in the reservoir and as a result liftoff of diatoms from the bottom and the input of this group added to plankton [55-58]. This is also visible in our results obtained from correlation analysis of the composition similarities for the sampling sites made in the JASP program. The results revealed similarities between sites located in different parts of the reservoir that composes a water heterogenic condition, as well as wind and water mixing.

Analyzing the main genera of the diatom composition in Sasyk benthos, revealed moderate pollution to the waterbodies of the Black Sea coastal waters, as well as for the Danube River flora [52-54]. The prevailing diatom species are distributed over the reservoir equally; however, for some sites (no. 6 and 7) the amount was more than $35 \%$ of relative abundance, and was presented by Rhoicosphenia abbreviata and Tabularia fasciculata. They are common species that sometimes prevail in algal communities in the coastal zone of Ukraine, which could also enter from Kogylnik and Sarata rivers [59,60]. Furthermore, Tabularia fasciculata is a mesohalobious species that is also observed in the coastal zone of rivers in the nearby territory known as the Sakarya River Basin, Turkey [61].

The role of waters coming from rivers entering into the coastal estuaries or reservoirs in the region are difficult not to overestimate, as the lack of this factor could lead to salinization of such waterbodies, which was marked for Kuyalnik Estuary Ecosystem [62]. Considering the drying out of the rivers coming into the Reservoir, together with the additional waters coming from Danube (using from the Danube-Sasyk Canal) it is essential for saving the diversity in the Sasyk ecosystem. The indicated composition represents an extensive history of becoming one of the largest seaside reservoirs in the northwest coastal zone of the Black Sea. In turn, the impact of outputs from the Kogylnik (Kunduk) and Sarata rivers, as well as the canal connecting Sasyk and Danube River waters are also traced. All of these circumstances have formed unique conditions for the Sasyk Reservoir. It may also be assumed that increasing amounts of species will be found with the rising number of sites and samples taken during different monitoring years. However, from the presented diversity, some species have never been registered in Ukraine before. Some rare taxa for Ukraine were also found $[63,64]$. Sellaphora difficillima is a well-known diatom from waters with contrasting features-from low saline environments. The occurrence of S. difficillima and Mastogloia laterostrata, which are mixed in terms of environmental requirements, as well as Fallacia clepsidroides and Amphora inariensis proves the ectopic nature of the site $6[13,14]$. However, some tendencies of diatoms preference, with regard to salinity (Nitzschia filiformis var. conferta, Opephora mutabilis, Rhaphoneis amphiceros, and Staurosira construens var. triundulata at site 1) or trophy (Cymbella proxima, Staurosira construens var. triundulata at site 6) can be observed here (Table S1). The probable reason for such diversity could be due to the ecotone conditions created by the mixture of highly mineralized water coming from a thick layer of sludge as well as freshwater inputs [33]. Such unstable salinity conditions with the range of $0.3-2.7 \mathrm{~g} \cdot \mathrm{L}^{-1}$ were observed during our investigations. In turn, future investigations of biodiversity of the Sasyk may will be focused regarding transparency of the Reservoir, and what impact the overgrowth of the banks by macrophytes will have on the diatom assemblages. 


\subsection{Ecological Characteristic of Sasyk}

The equally important part of this work was defining the current ecological characteristics of the Sasyk Reservoir as compared to the composition of benthic diatoms in the coastal zone of the Black Sea. For this, the environmental mapping along with measurements of temperature and conductivity demonstrated the impact of the Danube-Sasyk Canal. To determine the response of organisms to anthropogenic pressures, rather, the multimetric Diatom Index for Lakes (IOJ), based on phytobenthic diatoms was used. This index has never been applied to Ukrainian lakes; however, it is commonly used for assessment in the nearby territories of the Polish lakes $[44,65,66]$. The interpretation of indication results based on calculation of a multimeric Diatom Index for Lakes (IOJ), in general, confirmed the data regarding water quality in the Sasyk Reservoir obtained earlier during the phytoplankton investigation in the summer of 2013 [18]. As in previous investigations, the sites along the southern coast (sites no. 3 and no. 4) and in the northern part of the reservoir (at site no. 5) had a moderate status class. At sites no. 3 and no. 4, located along the left bank of the reservoir at its central region, the water quality class was defined as good and moderate, respectively. Apparently, it is due to the influence of the hydrological conditions at the sampling stations. Thus, stations no. 3 and no. 4 are located in gaps between thickets of higher aquatic vegetation and have not been exposed to any turbulence or undulation. On the contrary, site no. 6 is located near the Danube-Sasyk Canal inputs, and is unprotected from the constant hydrodynamical impact of water masses, that form from the influence of the north-easterly winds, which occurred during the sampling campaign. Likewise, this site is characterized by the minimum salinity of the water as studied before regarding the maximum impact of the Danube waters, as well as the possible agitation of the reservoir sediments, which are represented here as silt. Therefore, it quite possibly reduced the class of water quality to poor, and the study of phytoplankton indicators confirmed this [33]. As for site no. 7, located further from the inputs of the Canal, along the right bank, this status class is poor as well. In this case, the sampling site had thickets of Phragmites, notwithstanding the protection of the higher aquatic plants, the waves had a substantial impact due to the northeast wind effect. Moreover, the conditions for phytobenthos development on this site differ from others, since there is no solid substrate for fouling (stones from the dam, as found at other sites). This shore of the reservoir is also subject to active abrasion as well, which, perhaps, has induced the sediments to become more swollen under the influence of the waves, which the indicators reacted to. The Diatom Index demonstrated its potential usage in order to assess the trophic state for Ukrainian lakes. The obtained results present possibilities for future investigations and inspections of the Index efficiency for European lakes assessment.

\subsection{Salinity Changes Over the Sasyk Reservoir}

The next step of the work aimed to expose the salinity changes in the Sasyk Reservoir by analyzing the benthic diatom composition. Indication of the species list was assessed using the Halobien system $(\mathrm{H})$ according to the system of Hustedt [46] and van Dam et al. [10] with modern addition and taxonomical updates [47]. It is worth mentioning the efficiency of this method for the indication of salinity changes in lakes [67-70]. According to our results, more than half $(68 \%)$ of the identified species served as indicators of an above factor in the reservoir. The grouping of these indicators may give a picture as to nature's response to the changing of salinity over the years as well as the changing seasons of the studied waterbody. Prevailing numbers of typical preventatives of freshwater oligohalobes-indifferents, which can live in waters with a low amount of salinity as well as some amounts of oligohalobes-halophobes and oligohalobes that live only in the freshwaters, of the Sasyk Reservoir. In turn, oligohalobes-halophiles living in waters with low salinity and mesohalobes, which live in the estuaries and river mouths, give the possibility to conclude that the water in the Sasyk Reservoir, confirmed it to be mostly freshwater or else water from the lake with the presence of a slight number of solids. A relatively small amount of mesohalobes at sites 4 and 6 confirmed inputs of slightly mineralized waters from Danube, Sarata, and Kogylnik rivers, which retains the salinity level, or could even reduce it for the whole Reservoir. Environmental mapping illustratively reveals the 
impact of the waters from the mentioned rivers to the north as well as the impact of the Canal near the dam at the south testifying to the historical water genesis. The presence of oligohalobes-halophiles and mesohalobes seen by the range of salinity in a range of $0.5-2.31 \mathrm{~g} \mathrm{~L}^{-1}$ (Table 1), offer ideal conditions for the above-mentioned indicator groups' development. As is known, water with TDS of $0.5 \mathrm{~g} \mathrm{~L}^{-1}$ is appropriate for irrigation [47]. Thus, measurements, as well as the indication of salinity changes analyzing benthic diatom composition testified that the waters in the Sasyk Reservoir are inappropriate for re-wetting for now.

The future of the Sasyk Reservoir water usage in agriculture shows this to be currently impossible, as well as having a low fish capacity $[25,26]$. Thus, anthropogenic transformation of the waterbody into the estuary is a highly discussed issue $[30,31]$. However, our investigations, as well as the conclusions of other scientists, suggest that such kind of transformation can lead to another change in the species composition of diatoms, as well as other groups of algae, and its unpredictable transformation and, accordingly, the restructuring of the trophic chain of aquatic organisms and the hydroecosystem as a whole [27-29]. Targeted monitoring studies will be able to respond to the proposed changes in the ecosystem of the reservoir and its algae flora, and algae indicator species of diatoms indicate the degree of its anthropogenic transformation.

\section{Conclusions}

The conducted investigation of benthic diatom flora in the Sasyk Reservoir, which had not been studied since 1987, may supplement the understanding of the coastal zone of the Black Sea near Ukraine. The modern algal diversity is formed by heterogenic conditions of the studied area incorporated in diatom diversity. Diatoms represent 97 species (100 with infraspecies taxa), 13 taxa (proven to be rare for Ukraine), and three species were registered for the first time in Ukrainian water bodies. The indication of salinity using diatom composition revealed nature's response to heterogenic conditions of the studied area. The results suggest that the prevailing number of oligohalobes revealed the freshwater conditions of the reservoir. However, the presence of some amount of mesohalobes acknowledge conditions that are typical for estuaries and mouths of rivers, and reveal the salinity changes in the studied area. Understanding the presented findings, and the measured levels of salinity-it may well be assumed that the waters in the Sasyk Reservoir are inappropriate for use in an irrigation system for now. In turn, the current ecological characteristics of the Sasyk Reservoir were obtained via an analysis of diatom assemblages using multimeric Diatom Index for Lakes, which revealed alterations of the trophic state over the sites in reservoir from good, moderate, to poor status. The implementation of the Polish phytobenthos lake assessment method demonstrated possibilities for future usage of the Diatom Index for Lakes (IOJ) in the Ukraine, and presented insight as a potential for its further development for European lakes. According to the controversial issue, as for defining the future of the Sasyk Reservoir, the obtained results showing the current characteristics of the diatom composition provide the possibility of a pioneer investigation of the area, which would need to be supplemented with detailed monitoring.

Supplementary Materials: The following are available online at http://www.mdpi.com/1424-2818/12/12/0458/s1, Table S1: Distribution of the species composition of diatoms by sampling sites in the Sasyk Reservoir and its indicator values according to the Hustedt halobien system $(\mathrm{H})$.

Author Contributions: O.P.B. and A.Z.W. conceptualization of this study; investigation was made by O.P.B., N.O.I., and O.V.B.; methodology was prepared by O.P.B. and P.M.T.; statistics and mapping were prepared by S.B.; O.P.B., O.V.B., P.M.T., S.B., N.I., and A.Z.W. wrote and edited the manuscript. All authors have read and agreed to the published version of the manuscript.

Funding: This research was partially funded by the National Academy of Sciences of Ukraine and Polish Academy of Sciences. 
Acknowledgments: The authors express their appreciation for the critical review by anonymous reviewers that improved the manuscript. We would like to thank Ivanova V.N. in the organization of work processes. We are also very grateful to Trevor Williams for the proofreading of the English text. O.P.B. is indebted for a monthly study visit to Institute of Nature Conservation, Polish Academy of Sciences according to the Protocol to the Agreement on scientific cooperation between the Polish Academy of Sciences and the National Academy of Sciences of Ukraine.

Conflicts of Interest: The authors declare no conflict of interest.

\section{Appendix A}

Altogether, 97 species (100 infraspecies taxa) belonging to 38 genera of diatom algae were revealed during sampling period (Appendix A, Table S1). This was presented by 2 classes (Bacillariophyceae94 species (97 infr.), Mediophyceae-3 species), 14 orders (Bacillariales-20 species (22 infr.), Cocconeidales-10, Cymbellales-13, Eupodiscales-1, Fragilariales-11 (12 infr.), Licmophorales-4, Mastogloiales-2, Naviculales-20, Rhaphoneidales-1, Rhopalodiales-5, Stephanodiscales-2, Surirellales-2, Tabellariales-1, Thalassiophysales-5. The following taxonomical units were grouped by 22 families: Achnanthidiaceae-4 species, Amphipleuraceae-1, Bacillariaceae-20 (22 infr.), Catenulaceae - 5, Cocconeidaceae - 6, Cymbellaceae - 6, Diploneidaceae-1, Eupodiscaceae-1, Fragilariaceae-3, Gomphonemataceae - 6, Mastogloiaceae-2, Naviculaceae-16, Pleurosigmataceae-1, Rhaphoneidaceae - 1, Rhoicospheniaceae - 1, Rhopalodiaceae - 5, Sellaphoraceae - 2, Staurosiraceae - 8 (9 infr.), Stephanodiscaceae -2 , Surirellaceae -2 , Tabellariaceae -1 , Ulnariaceae -4.

\section{References}

1. Besse-Lototskaya, A.; Verdonschot, P.F.M.; Coste, M.; Van de Vijver, B. A new perspective for phytobenthos in the European water framework directive. Ecol. Indic. 2012, 18, 705-708. [CrossRef]

2. Schaumburg, J.; Schranz, C.; Hofmann, G.; Stelzer, D.; Schneider, S.; Schmedtje, U. Macrophytes and phytobenthos as indicators of ecological status in German lakes-A contribution to the implementation of the water framework directive. Limnologica 2004, 34, 302-314. [CrossRef]

3. Bennion, H.; Kelly, M.G.; Juggins, S.; Yallop, M.L.; Burgess, A.; Jamieson, J.; Krokowski, J. Assessment of ecological status in UK lakes using benthic diatoms. Freshw. Sci. 2014, 33, 639-654. [CrossRef]

4. Kelly, M.; Juggins, S.; Guthrie, R.; Pritchard, S.; Jamieson, J.; Rippey, B.; Hirst, H.; Yallop, M. Assessment of ecological status in U.K. rivers using diatoms. Freshw. Biol. 2008, 53, 403-422. [CrossRef]

5. Rimet, F. Recent views on river pollution and diatoms. Hydrobiologia 2012, 683, 1-24. [CrossRef]

6. Stenger-Kovács, C.; Lengyel, E.; Sebestyén, V.; Szabó, B. Effects of land use on streams: Traditional and functional analyses of benthic diatoms. Hydrobiologia 2020, 847, 2933-2946. [CrossRef]

7. Lengyel, E.; Szabó, B.; Stenger-Kovács, C. Realized ecological niche-based occupancy-Abundance patterns of benthic diatom traits. Hydrobiologia 2020, 847, 3115-3127. [CrossRef]

8. Kelly, M. Data rich, information poor? Phytobenthos assessment and the water framework directive. Eur. J. Phycol. 2013, 48, 437-450. [CrossRef]

9. Ponader, K.C.; Charles, D.F. Understanding the Relationship Between Natural Conditions and Loadings on Eutrophication: Algal Indicators of Eutrophication for New Jersey Streams. Final Report Year 3; Patrick Center for Environmental Research, Academy of Natural Sciences: Philadelphia, PA, USA, 2004; pp. 1-56.

10. Van Dam, H.; Mertens, A.; Sinkeldam, J. A coded checklist and ecological indicator values of freshwater diatoms from The Netherlands. Neth. J. Aquat. Ecol. 1994, 28, 117-133. [CrossRef]

11. Pardoa, I.; Delgadoa, C.; Abraína, R.; Gómez-Rodríguezb, C.; García-Rosellóc, E.; Garcíaa, L.; Reynoldsond, T.B. A predictive diatom-based model to assess the ecological status of streams and rivers of Northern Spain. Ecol. Indic. 2018, 90, 519-528. [CrossRef]

12. Stevenson, R.J.; Pan, Y. Assessing environmental conditions in rivers and streams with diatoms. In The Diatoms: Applications for the Environmental and Earth Sciences; Stoermer, S., Smol, J.P., Eds.; Cambridge University Press: Cambridge, UK, 1999; pp. 11-40.

13. Ács, É.; Bíró, T.; Berta, C.; Duleba, M.; Földi, A.; Grigorszky, I.; Hidas, A.; Knisz, J.; Korponai, J.L.; Trábert, Z.; et al. Long-term changes of species composition and functional traits of epiphytic diatoms in the Szigetköz region (Hungary) of the Danube river. Water 2020, 12, 776. [CrossRef] 
14. Bennett, M.G.; Lee, S.S.; Schofield, K.A.; Ridley, C.; Norton, S.B.; Webb, J.A.; Nichols, S.J.; Ogden, R.; Collins, A. Using systematic review and evidence banking to increase uptake and use of aquatic science in decision-making. Limnol. Oceanogr. Bull. 2018, 27, 103-109. [CrossRef]

15. Witkowski, A.; Lange-Bertalot, H.; Metzelin, D. Diatom flora of marine coasts I. In Iconographia diatomologica; Lange-Bertalot, H., Ed.; A.R.G. Gantner Verlag K.G.: Ruggell, Liechtenstein, 2000; Volume 7, pp. 1-925.

16. Wilson, J.; Basset, A.; West, R. Estuarine and lagoon biodiversity and their natural goods and services. Estuar. Coast. Shelf Sci. 2013, 132, 1-108. [CrossRef]

17. Lilitskaya, G.G.; Tsarenko, P.M.; Maslov, I.I. Bacillariophyta of lake Donuzlav (Crimea, Ukraine). Int. J. Algae 2013, 15, 135-152. [CrossRef]

18. Bilous, O.P.; Ivanova, N.O. Phytoplankton characteristics of the Sasyk reservoir (Ukraine). Int. J. Algae 2018, 20, 277-288. [CrossRef]

19. Newton, A.; Brito, A.C.; Icely, J.D.; Derolez, V.; Clara, I.; Angus, S.; Schernewski, G.; Inácio, M.; Lillebø, A.I.; Sousa, A.I.; et al. Assessing, quantifying and valuing the ecosystem services of coastal lagoons. J. Nat. Conserv. 2018, 44, 50-65. [CrossRef]

20. Marcos, C.; Gamito, S.; Umgiesser, G.; Pérez-Ruzafa, A. Coastal lagoons: Environmental processes, biological functioning and anthropogenic impacts. Estuar. Coast. Shelf Sci. 2019, 216, 1-240. [CrossRef]

21. Quintino, V.; Sangiorgio, F.; Mamedea, R.; Ricardoa, F.; Sampaioa, L.; Martinsa, R.; Freitasa, R.; Rodrigues, A.M.; Basset, A. The leaf-bag and the sediment sample: Two sides of the same ecological quality story? Estuar. Coast. Shelf Sci. 2011, 95, 326-337. [CrossRef]

22. Alekseenko, E.; Roux, B. Contribution to remediation of brackish lagoon: 3D simulation of salinity, bottom currents and resuspension of bottom sediments by strong winds. Estuar. Coast. Shelf Sci. 2019, 216, 27-37. [CrossRef]

23. Ivanova, N.O. Vodoshovishe Sasik—ekologo-gidrologichni problemi isnuvannya (Sasyk reservoir-ecological and hydrological problems of existence). Hydrol. Hydrochem. Hydroecol. 2009, 17, 113-117. (In Ukrainian)

24. Kharchenko, T.A.; Timchenko, V.I.; Ivanov, A.I.; Kolesnik, M.P.; Novikov, B.I.; Enaki, I.G.; Ryabov, A.K.; Sirenko, L.A.; Klokov, V.M.; Bashmakova, I.C.; et al. Bioproductivnost' i kachestvo vody Sasykskogo vodokhranilischa v usloviyakh ego opresneniya. In Bioproductivity and Water Quality Conditions in the Sasyk reservoir on its Desalination; Braginsky, L.P., Ed.; Nauk. Dumka: Kiev, Ukraine, 1990; pp. 1-276. (In Russian)

25. Lyashenko, A.V.; Zorina-Sakharova, Y.Y. Hydroecological characteristics of the Sasyk liman and the Sasyk reservoir. Hydrobiol. J. 2017, 53, 26-43. [CrossRef]

26. Lyashenko, A.V.; Zorina-Sakharova, Y.Y. Succession of hydrobiocenoses of the Sasyk liman and the Sasyk reservoir. Hydrobiol. J. 2018, 54, 14-29. [CrossRef]

27. Timchenko, V.M.; Ivanova, N.O. Ecological and hydrological view on the problems of the Sasyk estuary. In Proceedings of the North-Western Black Sea Coast: Current Hydroecological Problems and Ways to Solve Them, Materials All-Ukrainian scientific practice conference, Odessa, Ukraine, 12-14 September 2012; pp. 147-150.

28. Kharchenko, T.A. Sasyk Reservoir: Environmental problems of desalinated estuary. Bull. Acad. Sci. USSR 1988, 4, 63-67.

29. Timchenko, V.M.; Timchenko, O.V. Ecological aspects of hydrology in a navigable channel "The DanubeThe Black Sea" in Ukraine. In Proceedings of the 37th IAD Conference, Chisinau, Moldova, 29 October1 November 2008; pp. 229-231.

30. Vasenko, O.G.; Yeremenko, E.V. UkrNDIEP NAS of Ukraine. In Development of Socio-Economic and Environmental Justification for the Restoration of the Hydrological Regime of Lake Sasyk: Report under the Agreement (Final); Agreement № 11/1180/19/2; Research Institution “Ukrainian Research Institute of Environmental Problems" (UKRNDIEP): Kharkiv, Ukraine, 2004; pp. 1-215.

31. Rubel, O.E.; Burkinsky, B.V. Polipshennya ekologichnogo stanu ozera Sasyk: Zvit po Report on GDR/IPREED NAS of Ukraine. In Improving the Ecological State of Lake Sasyk; № DR0108U008999. without inv. №. 2009; Institute of Market Problems and Economic-Ecological Research of the National Academy of Sciences of Ukraine: Odessa, Ukrainian, 2008; pp. 1-60. (In Ukrainian)

32. Sasyk Lake. Available online: http://www.ramsar.org/sasyk-lake (accessed on 23 April 2020).

33. Bilous, O.P.; Barinova, S.S.; Ivanova, N.O.; Huliaieva, O.A. The use of phytoplankton as an indicator of internal hydrodynamics of a large seaside reservoir-Case of the Sasyk reservoir, Ukraine. Ecohydrol. Hydrobiol. 2016, 16, 160-174. [CrossRef] 
34. European Committee for Standardization. Water Quality-Guidance Standard for the Routine Sampling and Pretreatment of Benthic Diatoms from Rivers; CEN EN 13946; Comité Européen de Normalisation: Geneva, Switzerland, 2003; pp. 1-22.

35. Krammer, K.; Lange-Bertalot, H. Bacillariophyceae. 1. Teil: Naviculaceae. In Süßwasserflora von Mitteleuropa; Ettl, H., Gerlo, J., Heynig, H., Mollenhauer, D., Eds.; VEB Gustav Fisher Verlag: Jena, Germany, 1986; pp. 1-876.

36. Krammer, K.; Lange-Bertalot, H. Bacillariophyceae. 2. Teil: Epithemiaceae, Bacillariaceae, Surirellaceae. In Süßwasserflora von Mitteleuropa; Ettl, H., Gerlo, J., Heynig, H., Mollenhauer, D., Eds.; VEB Gustav Fisher Verlag: Jena, Germany, 1989; pp. 1-596.

37. Krammer, K.; Lange-Bertalot, H. Bacillariophyceae. 3. Teil: Eunoticeae. In Süßwasserflora von Mitteleuropa; Ettl, H., Gerlo, J., Heynig, H., Mollenhauer, D., Eds.; Gustav Fisher Verlag: Stuttgart, Germany, 1991; pp. 1-576.

38. Krammer, K.; Lange-Bertalot, H. Bacillariophyceae. 4. Teil: Achnanthaceae, Kritische Ergänzungen zu Navicula (Lineolatae) und Gomphonema. Teil 1-4. In Süßwasserflora von Mitteleuropa; Ettl, H., Gärtner, G., Gerloff, J., Heynig, H., Mollenhauer, D., Eds.; Gustav Fisher Verlag: Stuttgart, Germany, 1991; pp. 1-437.

39. Bakk, M.; Witkowski, A.; Żelazna-Wieczorek, J.; Wojtal, A.Z.; Szczepocka, E.; Szulc, A.; Szulc, B. Klucz do oznaczania okrzemek $w$ fitobentosie na potrzeby oceny stanu ekologicznego wód powierzchniowych w Polsce; Główny Inspektorat Ochrony Środowiska: Warszawa, Poland, 2012; pp. 1-452. (In Polish)

40. Kulikovskiy, M.S.; Glushchenko, A.M.; Genkal, S.I.; Kuznetsova, I.V. Identification Book of Diatoms from Russia; Filigran: Yaroslavl, Russia, 2016; pp. 1-804. (In Russian)

41. Lange-Bertalot, H.; Hofmann, G.; Werum, M.; Cantonati, M. Freshwater Benthic Diatoms of Central Europe: Over 800 Common Species Used in Ecological Assessment; Koeltz Botanical Books: Schmitten-Oberreifenberg, Germany, 2017; pp. 1-942.

42. Medlin, L.K.; Kaczmarska, I. Evolution of the diatoms: V. morphological and cytological support for the major clades and a taxonomic revision. Phycologia 2004, 43, 245-270. [CrossRef]

43. Guiry, M.D.; Guiry, G.M. AlgaeBase, World-wide Electronic Publication; National University of Ireland Press: Galway, Ireland, 2020.

44. Bielczyńska, A. Bioindication on the basis of benthic diatoms: Advantages and disadvantages of the Polish phytobenthos lake assessment method (IOJ—the Diatom Index for Lakes)/Bioindykacja na podstawie okrzemek bentosowych: Mocne i słabe strony polskiej metody oceny jezior na podstawie fitobentosu (IOJ-Indeks Okrzemkowy Jezior) Environmental Protection and Natural Resources. J. Inst. Environ. Prot. Natl. Res. Inst. 2015, 26, 48-55. (In Polish) [CrossRef]

45. Rozporządzenie Ministra Gospodarki Morskiej i Żeglugi Śródlądowej z dnia 9 października 2019 r. w sprawie form i sposobu prowadzenia monitoringu jednolitych części wód powierzchniowych i jednolitych części wód podziemnych. Dz. Ustaw Rzeczyposp. Pol. 2019, 2147, 1-98. (In Polish)

46. Hustedt, F. Systematische und ökologische Untersuchungen über die Diatomeen-Flora von Java, Bali und Sumatra nach dem Material der Deutschen Limnologischen Sunda-Expedition. I. Systematischer Teil. Archiv Hydrobiol. 1938, XV, 131-177.

47. Barinova, S.S.; Bilous, O.P.; Tsarenko, P.M. Algoindicatsiya vodnykh ob'ektov Ukrainy: Metody i perspektyvy (Algal indication of water bodies in Ukraine: Methods and perspectives); University of Haifa Publisher: Haifa, Israel; Kiev, Ukraine, 2019; pp. 1-367.

48. Jonsson, J.; Smedfors, K.; Nyholm, L.; Thornell, G. Towards chip-based salinity measurements for small submersibles and biologgers. Int. J. Oceanogr. 2013, 2013, 1-11. [CrossRef]

49. Sharma, A.; Kundu, S.S.; Tariq, H.; Kewalramani, N.; Yadav, R.K. Impact of total dissolved solids in drinking water on nutrient utilisation and growth performance of Murrah buffalo calves. Livest. Sci. 2017, 198, 17-23. [CrossRef]

50. Malmberg, C.G. Electrical conductivity of dilute solutions of 'sea water' from 5 to 120. C. J. Res. Natl. Bur. Stand. A Phys. Chem. 1965, 69, 39-43. [CrossRef]

51. Love, J.; Selker, R.; Marsman, M.; Jamil, T.; Dropmann, D.; Verhagen, A.J.; Ly, A.; Gronau, Q.F.; Smira, M.; Epskamp, S.; et al. JASP: Graphical statistical software for common statistical designs. J. Stat. Softw. 2019, 88, 1-17. [CrossRef]

52. Kivrak, E.; Uygun, A. The structure and diversity of the epipelic diatom community in a heavily polluted stream (the Akarçay, Turkey) and their relationship with environmental variables. J. Freshw. Ecol. 2012, 27, 443-457. [CrossRef] 
53. Snigireva, A.A.; Kovaleva, G.V. Diatom algae of sandy spits of the northwestern part of the Black Sea (Ukraine). Int. J. Algae 2015, 17, 107-130. [CrossRef]

54. Van Dam, H.; Stenger-Kovács, C.; Ács, É.; Borics, G.; Buczkó, K.; Hajnal, É.; Soróczki-Pinter, É.; Várbiró, G.; Tóthmérész, B.; Padisák, J. Implementation of the European water framework directive: Development of a system for water quality assessment of Hungarian running waters with diatoms. Large Rivers 2007, 17, 339-364. [CrossRef]

55. Timchenko, V.M. Ecological Hydrology of Waterbodies in Ukraine; Naukova Dumka: Kyiv, Ukraine, 2006; pp. 1-384. (In Ukranian)

56. Timchenko, V.M.; Litvinov, A.S.; Kolesnyk, M.P.; Poddubny, S.A. Water circulation in Sasyk Reservoir. Hydrob. J. 1988, 24, 67-73. (In Russian)

57. Ivanova, N.O. Water exchange as a factor of the formation of modern conditions and the function of the Sasyk Reservoir ecosystem. Series: Biology. Special issue: Assessment of the ecological state of waterbodies and adaptation of hydrobionts. Sci. Notes Ternopil Nat. Pedagogical Univ. V. Hnatyuk 2015, 3-4, $274-277$. (In Ukranian)

58. Ivanova, N.O. Pecularities of the water masses mixing at the Sasyk Reservoir. In Proceedings of the Meteorology, Hydrology, Monitoring of Environment in the Context of Ecological Challenges of Nowadays; Materials of All-Ukrainian conference of young people, Kyiv, Ukraine, 16-17 November 2016; pp. 27-29. (In Ukranian).

59. Myronjuk, A.N.; Tkachenko, F.P. Composition of algae indicators of small rivers in the northwestern of the Black Sea. Bulletin Kharkiv Nat. Agric. Univ. Biol. Ser. 2013, 2, 93-102.

60. Environmental Monitoring in the Black Sea. National Pilot Monitoring Studies and Joint Open Sea Surveys in Georgia, Russian Federation and Ukraine. Draft Final Scientific Report, 2017; Slobodnik, J., Alexandrov, B., Komorin, V., Mikaelyan, A., Guchmanidze, A., Arabidze, M., Korshenko, A., Eds.; EU/UNDP Project: Improving Environmental Monitoring in the Black Sea-Phase II (EMBLAS-II) ENPI/2013/313-169; 2018; pp. 1-573. Available online: http://emblasproject.org/wp-content/uploads/2019/07/EMBLAS-II_NPMS_JOSS_ 2017_ScReport_FinDraft2.pdf (accessed on 30 November 2020).

61. Solak, C.N.; Peszek, Ł.; Yilmaz, E.; Ergül, H.A.; Kayal, M.; Ekmekçi, F.; Várbíró, G.; Yüce, A.M.; Canli, O.; Binici, M.S.; et al. Use of diatoms in monitoring the Sakarya river basin, Turkey. Water 2020, 12, 703. [CrossRef]

62. Tsarenko, P.M.; Ennan, A.A.; Shikhaleyeva, G.N.; Barinova, S.S.; Gerasimiuk, V.P.; Ryzhko, V.E. Cyanoprokaryota of the Kuyalnik estuary ecosystem (Ukraine). Int. J. Algae 2016, 18, 337-352. [CrossRef]

63. Gerasimiuk, V.P.; Gerasymova, O.V.; Struk (Konischuk), M.O.; Terenko, G.V.; Tsarenko (Bilous), O.P.; Tsarenko, P.M.; Wasser, S.P. Algae of Ukraine: Diversity, Nomenclature, Taxonomy, Ecology and Geography Bacillariophyta; Tsarenko, P.M., Wasser, S.P., Nevo, E., Eds.; A.R.G. Gartner Verlag Kommandit Geselschaft: Ruggel, Liechtenstein, 2009; Volume 2, pp. 1-413.

64. Berezovskaya, V.Y. Species diversity of algae of the Kiev upland rivers (Ukraine). Int. J. Algae 2019, 21, 43-66. [CrossRef]

65. Picińska-Fałtynowicz, J.; Błachuta, J. Methodological Guidelines for Assessing the Ecological Status of Bodies of Rivers and Lakes and the Ecological Potential of Artificial and Heavily Modified Bodies of Running Waters in Poland on the Basis of Phytobenthos Surveys/Wytyczne Metodyczne Do Przeprowadzenia Oceny Stanu Ekologicznego Jednolitych Części Wód Rzek I Jezior Oraz Potencjału Ekologicznego Sztucznych I Silnie Zmienionych Jednolitych Części Wód Ptynacych Polski Na Podstawie Badań Fitobentosu; Chief Inspectorate for Environmental Protection: Wrocław, Poland, 2010; pp. 1-79. (In Polish)

66. Kelly, M.; Ács, É.; Bertrin, V.; Bennion, H.; Borics, G.; Burgess, A.; Denys, L.; Ecke, F.; Kahlert, M.; Karjalainen, S.M.; et al. Water Framework Directive Intercalibration Technical Report: Lake Phytobenthos Ecological Assessment Methods; Poikane, S., Ed.; Publications Office of the European Union: Luxembourg, 2014; pp. 1-140. ISBN 978-92-79-35468-7.

67. Fritz, S.; Cumming, B.; Gasse, F.; Laird, K.R. Diatoms as indicators of hydrologic and climatic change in saline lakes. In The Diatoms: Applications for the Environmental and Earth Sciences, 2nd ed.; Smol, J.P., Stoermer, E.F., Eds.; Cambridge University Press: Cambridge, UK, 2010; pp. 186-208. [CrossRef]

68. Fritz, S.C. Salinity and Climate Reconstructions from Continental Lakes. In Encyclopedia of Quaternary Science, 2nd ed.; Elias, S.A., Mock, C.J., Eds.; Elsevier: Amsterdam, The Netherlands, 2013; pp. 507-515. 
69. Kopyrina, L.; Pshennikova, E.; Barinova, S. Diversity and ecological characteristic of algae and cyanobacteria of thermokarst lakes in Yakutia (northeastern Russia). Oceanol. Hydrobiol. Stud. 2020, 49, 99-122. [CrossRef]

70. Jiyenbekov, A.; Barinova, S.; Bigaliev, A.; Nurashov, S.; Sametova, E.; Fahima, T. Ecological diversity of algae in the Alakol Lake Natural Reserve, Kazakhstan. Bot. Pac. A J. Plant Sci. Conserv. 2019, 8, 63-74. [CrossRef]

Publisher's Note: MDPI stays neutral with regard to jurisdictional claims in published maps and institutional affiliations.

(C) 2020 by the authors. Licensee MDPI, Basel, Switzerland. This article is an open access article distributed under the terms and conditions of the Creative Commons Attribution (CC BY) license (http://creativecommons.org/licenses/by/4.0/). 